A demonstration of the new optical meteorograph was given by Mr. J. Patterson, secretary of Section III., by which the temperatures and pressures may be indicated in the upper atmosphere at night by means of electric light flashes. Prof. A. Norman Shaw was elected president of the Section for the coming year.

In Section IV. (geological and mineralogical sciences) thirty-one papers were presented. The meetings of the Section opened with the address of the president, Dr. E. M. Kindle, on "A New Viewpoint on Palæontology ", in which he explained the preparation of a printed card index illustrating and describing type fossils. The attention of the Section was mainly occupied with a symposium on batholiths, H. C. Horwood, J. S. DeLury, T. T. Quirke, E. L. Bruce, J. A. Dresser, S. J. Schofield, W. T. Wright, and D. R. Derry contributing.

Papers on the late glacial history of the Great Plains were read by W. A. Johnston and D. A. Nichols, and E. S. Moore described an old glacial valley on Michipicoten River, northern Ontario. Papers also dealt with the following subjects: "The Devonian and Siberian Rocks of Gaspe and Northern New Brunswick, and Topographic Deflections in the Gaspe Peninsula" (F. J. Alcock); "A New Lower Jurassic Fauna in the Rocky Mountains" (P. S. Warren); and "The Re-crystallisation of Gypsum, illustrated by Microphotos on Cinema Films " (G. M. Thomson). Other papers were read by titles and will appear in the transactions. Mr. W. A. Johnston was elected president of the Section for the coming year.

In Section V. (biological sciences) sixty-six papers were presented. The presidential address by Dr. Jas. Miller was on the subject of "The Glomerulus of the Kidney: An Anatomical and Pathological Study ". As an historical review and a summary of recent work, the address, printed in the proceedings, will be useful. Botanical papers came first. Frère Marie-Victorin presented a series of papers by himself and co-workers, extending their important phytogeographical and taxonomic studies of the flora of the north-eastern part of Canada. Various new relic species were described.

F. E. Lloyd classified Utricularia species according to their trap mechanism. G. W. Scarth presented a paper by himself and A. B. Brown on the "Effects of Temperature on Stomata"; A. H. R. Buller showed that a yeast Sporobolomyces discharges aerial spores in the same manner as Basidiomycetes, and should probably be classed among the latter. $\mathrm{He}$ also described the phenomenon of puffing in the Discomycetes. Papers presented by W. P. Thompson were taken as read in his absence.

Anatomical, biochemical, pathological, and physiological topies were dealt with by the majority of the papers in this Section. Mention may be made of the following : Pierre Masson, "Sur les propriétés organogéniques des cellules de Schwann ". J. G. Fitzgerald and co-workers were responsible for some seventeen papers on toxins, sera, etc. Among the more notable were: the account by N. E. McKinnon and Wm. Knowles of "A Concentrated Anti-Vaccinal Serum" which may prove to be of value; that by C. H. Best, H. C. Foster, and L. Irving on "The Fate of the Sugar which disappears under the Action of Insulin " (confirming and extending the work of Best, Hoet, Marks, and Dale); and that by A. F. Charles and D. A. Scott on "Acetylation of Crystalline Insulin". Hardolph Wasteneys presented, among others, an interesting paper by H. D. Jenner and H. D. Kay on "The Place of Mg in the Phosphatase System ", also one by A. A. Fletcher and Florence Hargreaves on "The Colon Condition in Rats with Vitamin B Deficiency ", and one with B. F. Crocker, entitled "A Note on the Equilibrium of Peptic Synthesis".

Several papers were presented by V. J. Harding, of which one by T. F. Nicholson on "The Effect of Large Amounts of Urea on the Acid-Base Equilibrium of the Dog" raised the unanswered question of whether urea can function as a base; and another by Harding and D. E. Selby described how yeast (which ordinarily will not hydrolyse galactose) can be trained to do so in three generations, and can be used accordingly in urine analyses.

Among the more significant of the papers presented by Dr.J. B. Collip was one by J. W. Allardyce and L. I. Pugsley on "A Comparison of the Effect of Vitamin $\mathrm{D}$ and the Parathyroid Hormone on the Calcium and Phosphorus of Serum and Urine ". Dr. Collip summarised in another contribution the physiological and chemical properties of the placental hormones. B. P. Babkin, in a paper on "The Innervation of the Salivary Glands", described the different effect of parosympathetic and sympathetic nerves on these glands. Jas. Miller, F. R. Miller, and V. E. Henderson also presented papers.

On zoological topies only a few papers were presented, namely, one by C. McLean Fraser on the ecology of the cockle; two by E. Home Craigie (presented by B. A. Bensley) on the cerebral anatomy of the humming bird and of the wild Norway rat $v$. albino, respectively; and one by $\mathrm{A}$. Willey, entitled "Glossobalanus Berkleii, a New Enteropneust from the West Coast". Dr. J. B. Collip was elected president of the Section.

The president of the Society for the ensuing year is Sir Robert Falconer, Principal of Toronto University, and the vice-president, Prof. F. E. Lloyd of McGill. It is hoped that the 1932 meeting will take place in Vancouver, but no definite arrangement has yet been made.

\title{
Conference of Empire Survey Officers, I93I.
}

THE second conference of Empire Survey. Officers, convened by the Secretary of State for the Colonies, was held on July 8-28, and, as a result of a decision taken at the first Conference in 1928, was devoted mainly to the subject of cadastral and property surveys and land registration. At the same time, opportunities were taken for giving attention to other branches of survey.

The meetings were held generally at the Science Museum, placed at the disposal of the Conference by Sir Henry Lyons, representing the Board of Education; but meetings were held also at the War Office, Surveyors' Institution, University of Cambridge, Admiralty, the Thames (Port of London Authority),
Nautical Almanac Office, Royal Observatory, Southampton. (Ordnance Survey), Liverpool Observatory and Docks, York, and Hull. At the last port delegates were permitted by the Admiralty to observe hydrographical methods on two of H.M. surveying ships operating in the North Sea.

Of the Dominions, Canada, New Zealand, and Newfoundland were unfortunately unable to send delegates, and of the Colonies only fourteen were. represented, the world-wide depression being mainly responsible. In practically all cases, delegates were either survey officers at home on periodic leave or for other reasons.

The pressing need for extensive revision of the

No. 3224, VoL. 128] 
Ordnance large-scale maps of Great Britain was brought to notice by Sir Charles Close, sheets in some cases being forty years out of date. Methods of map reproduction at home and in the tropics were discussed at the Ordnance Survey, Southampton, where Brigadier H. St. J. L. Winterbotham, the initiator and president of the Conference, and Major Clough, gave a description of the latest methods and processes of map-making. Triangulation was discussed by Dr. de Graaff Hunter and Capt. Calder Wood ; traverses by $\mathrm{Mr}$. J. Clendinning; gravimetry and the training of European surveyors were treated at Cambridge by Sir G. P. Lenox-Conyngham, Col. Craster, Prof. F. Debenham, and others; while Sir John Flett gave a remarkably lucid lecture on geophysical surveying, and Drs. Jeffreys and Hunter dealt with the relations between geophysics and geodesy. Air survey was brought forward by Capt. M. Hotine, air photography by Flight-Lieut. J. Bussey, aeronautical maps by Squadron Leader P. H. Mackworth, and air survey as applied to cadastral mapping in India by Col. R. $\mathbf{H}$. Phillimore; a paper on the airman-surveyor by $\mathrm{Mr}$. P. E. L. Gethin provoked a lively discussion. Admiral H. P. Douglas, to whom the success of the Conference was due in no small measure, described hydrographical methods. A summary presentation of the present knowledge of tides in British waters was given by Prof. J. Proudman, following an admirable description of tidal instruments by Prof. A. T. Doodson; Comdr. E. C. Shankland lectured on the hydrology of the Thames estuary. Optical distance measurement was dealt with by Major R. L. Brown, and the possible improvement of the barometer was not ignored. Sir Henry Lyons described early methods of survey in Egypt and the Roman Empire. The AstronomerRoyal gave the results of the most recent experience on the reception of $W / T$ signals, and Dr. L. J. Comrie gave a lecture on the Nautical Almanac and mechanical computation.

It will be seen that much ground was covered out. side the main work of the Conference. Within this sphere there was an eloquent address from Sir John Stewart-Wallace on land registration in Britain.
Papers on land survey were sent by Mr. F. H. Peters, Surveyor-General of Dominion Lands, Canada, by Mr. A. H. G. Dawson, Surveyor-General of Ceylon, and by Mr. W. F. N. Bridges for the Surveyor-General of Malaya, the latter being a complete account of the survey and registration in that Colony. Mr. Maxwell Edwards, Surveyor-General of the Transvaal, and Mr. W. G. Fairweather of Northern Rhodesia read papers on property surveys and registration in their respective spheres. Lieut.-Col. C. H. Ley sent a paper describing the somewhat difficult cadastral structure of Palestine; another came from Mr. C. O. Gilbert, the Director of Surveys in Kenya. Col. M. O'C. Tandy annotated a paper by Cols. Campbell and Gwynn on rectangulation surveys in India, which bear some relation to the system in the Prairie Provinces of Canada; the discussion was continued by Colonel MacLeod, Chief of the Geographical Section of the General Staff, whose organising ability contributed greatly to the success of the meetings, at which he often took the chair in the absence of the president. It is not possible to summarise all the work done by willing hands in the field of land survey, but it may be said that there were few of the difficulties in the Empire which were not ventilated. A most instructive exhibit of cadastral maps was arranged at the Science Museum by the spontaneous labours of Sir E. M. Dowson; this was by no means limited to the Empire, since France, Italy, Switzerland, and Egypt made generous contributions, often involving a considerable amount of work.

Other subjects discussed were topography, the training of native surveyors, the Empire Survey Review, the Field Survey Association, and the position of the licensed surveyor in Canada, Kenya, Trinidad, etc.

These first two conferences have owed their success largely to the efforts of Sir Cecil Bottomley and to Mr. E. B. Bowyer, chairman and joint secretary of the Colonial Survey Committee. The proceedings will be published by H.M. Stationery Office early next year. It was decided to recommend the convening of a third Conference in 1934.

\section{Coloured Glass as a Deterrent to House Flies.}

$\mathrm{A}^{\mathrm{N}}$ interesting series of tests with the object of finding whether rooms glazed with 'Calorex' are likely, by virtue of the special properties of the glass, to be freer from insects than rooms glazed with ordinary glass has recently been carried out at the Imperial College of Science and Technology under the supervision of Prof. J. W. Munro, on behalf of Messrs. Chance Brothers and Co., Ltd.

Calorex glass is of a pale greenish-blue tint, and is designed to afford protection from excessive solar radiation by strongly absorbing infra-red radiation whilst transmitting in a useful degree the radiation within the visible spectrum. The present experiments, which have been conducted with several types of insect, but mainly with flies, bees, and wasps, confirm and amplify observations made at the Building Research Station at Garston, Herts, and described by Mr. H. E. Beckett in Nature. 1

House flies (Musca domestica) exposed to sunlight in a box, one half of which was glazed with Calorex and the other with ordinary glass, showed a marked preference for the ordinary glass, the ratio of the numbers of insects in the two halves, averaged over several experiments, being about $9: 4$. These results were verified by other tests in which the insects were not enclosed within the box but were attracted to it by a suitable bait. Wasps and bees were found to behave in the same way as flies.
Much of the preference shown is ascribed to the inequality of temperatures beneath the two kinds of glass, the disparity in insect population being greatest when the maximum temperature differences were observed. Confirmatory evidence of a positive effect with temperature differences maintained by agencies other than radiation is not, however, chronicled.

That an effect can definitely be ascribed to the colour of the light which has passed through Calorex was demonstrated by an experiment in which bees were enclosed in a glass cylinder, one end of which was closed with Calorex and the other with ordinary glass. By interchanging the glasses an immediate reaction was obtained, the bees moving to the end covered with ordinary glass.

The effect of coloured light does not seem to be peculiar to blue light. Messrs. Pilkington Brothers, Ltd., from experiments conducted last year, have stated $^{2}$ that the house fly prefers white light to coloured light, and that red and yellow are the best deterrents, being considerably more effective than blue and green. On the other hand, it has been stated $^{3}$ that blue glass is completely effective.

The most extensive use of coloured glass for this purpose at present seems to be in meat stores. In such buildings yellow glass is unpopular on account of the sickly appearance which it imparts to the meat, and blue glass has been used with some success. In 